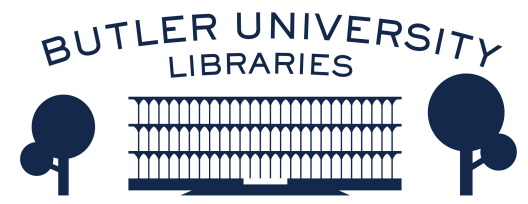

Journal of Hindu-Christian Studies

\title{
Theōsis: A Comparative Study of T. F. Torrance and Rāmānuja
}

Steven Tsoukalas

Emmaus Biblical Seminary

Follow this and additional works at: https://digitalcommons.butler.edu/jhcs

Part of the Christianity Commons, Hindu Studies Commons, and the Religious Thought, Theology and Philosophy of Religion Commons

\section{Recommended Citation}

Tsoukalas, Steven (2017) "Theōsis: A Comparative Study of T. F. Torrance and Rāmānuja," Journal of Hindu-Christian Studies: Vol. 30, Article 7.

Available at: https://doi.org/10.7825/2164-6279.1659

The Journal of Hindu-Christian Studies is a publication of the Society for Hindu-Christian Studies. The digital version is made available by Digital Commons @ Butler University. For questions about the Journal or the Society, please contact cbauman@butler.edu. For more information about Digital Commons @ Butler University, please contact digitalscholarship@butler.edu. 


\section{Theōsis: A Comparative Study of T. F. Torrance and Rāmānuja}

\section{Steven Tsoukalas Emmaus Biblical Seminary}

THIS essay is an imaginative conversation as I engage two religious thinkers-the prolific Reformed theologian Thomas F. Torrance (19132007) and the great Vedāntin Rāmānuja (traditionally, 1017-1137). I will compare Torrance's theology ${ }^{1}$ of theōsis ${ }^{2}$ (participation in the life of God) and theōria (contemplation as a way of participation in the life of God) with those of Rāmānuja. Though the words themselves were likely unknown to Rāmānuja, through his works one can see a notion of theōsis.

I first probe Torrance's theology, then move to Rāmānuja in conversation with Torrance.

Athanasius and his Eastern-tradition theology (theōsis included) influenced Torrance, a Patristics scholar. ${ }^{3}$ Simple perusal of Torrance's works evidences the profound impact Athanasius had on him. Athanasius was a champion of the Trinity doctrine and a powerful foe of Arius of Alexandria, who denied the full deity of Jesus. Athanasius' theology was firmly instantiated in the Trinity, seeing all theological events, including the Son's homoousion ([of the] same essence) with the Father, dynamically within the Triune life. For Athanasius, theōsis stems from the Son's reconciling work, which took place at the incarnation, continued through the cross event, and continues into the eschaton. ${ }^{4}$

Karl Barth's theology also impacted Torrance. ${ }^{5}$ Torrance often noted Barth's Trinitarian emphasis, especially Barth's insistence that all theological events be seen as occurring within the life of the Trinity. As such, Torrance, true to Barth, would reject a "dualism" that severed theological categories (especially the acts and attributes of God from the being of God) from Trinitarian moorings. ${ }^{6}$ This dualism, according to Torrance, characterizes much of Western theology. ${ }^{7}$ Consequently, under Barth's (and Athanasius') influence Torrance argued for a "unitary" model for doing theology. ${ }^{8}$

Torrance's theology sits in an ontology (a discourse on God, the world and the soul, and

Steven Tsoukalas is Professor and Chair of Apologetics and World Religions at Emmaus Biblical Seminary, Haiti. He earned a PhD from the University of Birmingham (UK) in Hindu Theology and Philosophy, a ThM in World Religions (Hindu Studies) at Harvard University, and an MDiv at Gordon-Conwell Theological Seminary. His areas of focus are comparative theological studies in Hinduism and Christianity, the Bhagavadgita, and Vedanta theology and philosophy. His publications include a sixvolume exegetical commentary on the Bhagavadgita (Edwin Mellen, 2007-2015); articles in the Journal of Vaishnava Studies; and Kṛșna and Christ: Body-Divine Relation in the Thought of Śañkara, Rāmānuja, and Classical Christian Orthodoxy (Wipf and Stock, 2006). 
their connections) of the Triune God as wholly other than creation, creatio ex nihilo, creation (including souls) as finite and dependent upon God, and creation (including souls) after the fall one day being reconciled to God.

We do well also to consider theological predicates for God. "God" is not a category separate from trinitological articulation. In line with Nicaea, Torrance affirms that the Triune God alone is eternal Being as three persons. Second, Torrance affirms the Chalcedonian Definition regarding the one person of Christ as fully theos (God) and fully man. Third, Torrance sees Christ as uniquely and everlastingly fully theos and fully man.

What, then, does theōsis look like? What is theōria in relation to theōsis?

Theōsis (from theoō, I make divine) entails "the emancipation of man from imprisonment in himself and the lifting of him up to partake of the living presence and saving acts of God the Creator and Redeemer." " Though there are several biblical verses by which one gathers the notion of theōsis, ${ }^{10} 2$ Peter 1.4 is significant, where believers are exhorted to be "partakers of the divine nature" (theias koinōnoi phuseōs).

The word theōsis is not in the New Testament. Though using non-biblical terms to elucidate theology does not bother Torrance, the term for him is still an unfortunate one. It translates as "deification." But humans, asserts Torrance, can never become God. ${ }^{11}$ Moreover, humanity is a creation contingent upon the eternal Triune God. So there is no ontological transformation into the divine essence. Additionally, for koinōnoi Torrance prefers the translation "partners" to that of "partakers." ${ }^{12}$ Here the relational aspect of believers in fellowship with the Triune God is paramount. For this reason I prefer "participants."
Yet, Torrance is not averse to an ontological transformation of believers' humanity. Here Torrance keeps with Chalcedon: Jesus is "homoousion with us according to the humanity." Further, the incarnation of the Son, occurring within the life of the Trinity, undergirds the sanctifying ontological and functional transformation of humanity toward fulfillment of what Eden was intended to be. There, Adam and Eve, made in the image of God, enjoyed fellowship (theōsis) and contemplation (theōria ${ }^{13}$ ) through "onto-relations" with God and with each other. Thus, what made Adam and Eve truly human is proper image-of-God relations. ${ }^{14}$

Catastrophically, at the fall true humanity was effaced. Remedially, God the Son, the Image of the invisible God, incarnated, descending into our humanness as the image of the first Adam. Taking this humanness upon himself in order to redeem it, and being truly human in the perfect wedding of image and Image, he fulfilled what Adam was intended to be.

"Truly human" therefore entails fellowship (theōsis), through reconciliation, with the Triune God through the reconciling act of the incarnate Son, the understanding of which is theōria, sanctifying and enlightening contemplation/ understanding. Torrance states that "the proper understanding of God as Father, Son and Holy Spirit takes place only within the movement of atoning propitiation whereby God draws near to us and draws us near to himself in believing response and brings us into union with himself through the gift of his Spirit." ${ }^{15}$ The relationship is reciprocally vertical: the Triune God toward believers through Christ (who is the Image of God the Father) in communion with the Holy Spirit; and believers toward the Triune God. It is also horizontal: human-to-human. The Eastern tradition calls this "Christification," being 
conformed to the "image of Christ." Believers in Christ are transformed into "the image of the Image." Christ effects this through his hypostatic union. ${ }^{16}$ Christ, by virtue of the perfect, everlasting wedding of his deity with his humanity, mediates theōsis through the sanctifying work of the Spirit.

Through the theōtic activity of God the Holy Spirit, reconciliation in part entails a theorria (contemplation) that enables believers both to apprehend and comprehend what the Triune God reveals of himself in Christ. In turn, functionally theōria/theōsis rightly fulfills humanity's "transcendental determinism of our own being for God." ${ }^{17}$ Determinism for the Transcendent, or humanity's innate need to reach to the Transcendent, was rightly in place in the Garden, but was marred by the fall. Today, humanity's transcendental determinisms express in myriads of ways. Torrance holds that only by the grace and action of the Holy Spirit, who points to the incarnate Son, can humans rightly determine the Transcendent.

In comparative conversation with Rāmānuja I now explore eleven themes related to Torrance's theōsis: ontology as paradigm; predicates for "God"; theōsis; homoousios; means of theōsis; supreme Lord Viṣnu-Nārāyaṇa; theōria; key texts for theōsis; ontological transformation of humanity; true humanity; and transcendental determinism. These are not treated separately but interwoven in conversation.

Rāmānuja's ontology is viśisțādvāita (qualified non-dualism). Rāmānuja's God is Lord Viṣnu-Nārāyaṇa, who is personal, non-dual, and all. The Lord is ultimate reality. Yet, the Lord as ultimate reality/all is "qualified" (viśișta) by bheda (difference)-there is bheda between Viṣnu-Nārāyaṇa, the universe, and àtman-s (souls). Further, the universe and attman-s are the body of the Lord, are real, and are ontologically equal with the Lord.

Though bheda exists both in the functional and the ontological-because Viṣnu-Nārāyaṇa originates ${ }^{18}$ dependent reality ex deo (in recurring cycles of dissolution and origination)-I focus here briefly on the functional. Since the Lord originates, one function is his transcendence over all. Gitā 7.7 reads, "There is nothing else whatsoever higher than me ... On me all this universe is strung like pearls on a thread." ${ }^{19}$ Yet, the Lord is also antaryāmin, "inner controller." Sentient and non-sentient reality is therefore dependent on the Lord, who controls and sustains. ${ }^{20}$ Lastly, in addition to the universe as the Lord's body is Rāmānuja's unique doctrine of the divya rūpa, Lord Viṣnu-Nārāyaṇa's personal "divine form." Importantly, the divya rūpa is real but non-prakrtic, meaning the divya rūpa is not karmic-tainted. ${ }^{21}$

Rāmānuja and Torrance exhibit notional similarities regarding theōsis, which afford comparative analyses. Yet, when ontologies figure in, differences between the two theologians arise. For example, with Rāmānuja, though we see theōsis as partaking of and participating in the divine nature, in contrast to Torrance all humans, not just devotees, partake of and participate in the divine nature, in part because they share originated ontological oneness with the Lord (cf. Gitā 7.4-11,19).

Torrance also shares with Rāmānuja the notion of emancipation and partaking of presence. Torrance describes theōsis as "the emancipation of man from imprisonment in himself and the lifting of him up to partake of the living presence and saving acts of God the Creator and Redeemer." Rāmānuja claims the saving act of emancipation from imprisonment, 
specifically karmic-embodied imprisonments of everlasting individual ātman-s. Emancipation occurs by the grace of Lord Viṣnu-Nārāyaṇa when he descends into human form as Kṛșna and offers himself to devotees (Gìtā 4.6-8; 9.11; 18.62). Further, there is partaking of presence at least in two ways, both involving bheda. First, human individuality provides context for the indwelling presence of the Lord as antaryāmin ${ }^{22}$; second, the Lord is the supreme transcendent one.

With Kṛșna as avatāra (descent [of God in human form]), Rāmānuja's ontology lends to a "god-man" doctrine. Since the material universe is real, Kṛ̣ṇa is Viṣnu-Nārāyaṇa in real "human form" (mānuṣi tanu, Gìtā 9.11) descending by grace to bring ignorant ${ }^{23}$ humanity to communion, theōsis, with himself. ${ }^{24}$ Here is a type of hypostatic union notionally similar to Christ's, though there is a major difference. I argue elsewhere that even intraRāmānuja, Kṛṣna's mānuṣi tanu does not identify with humanity, due largely to the divya rūpa as material cause for Kṛ̣ṇa's mānuṣi tanu. ${ }^{25}$ Torrance posits Christ's humanity ex nihilo (by way of Adam and Eve), so intra-Christianity there is identification. Interestingly, Kṛșna as avatāra is homoousios with Viṣnu-Nārāyaṇa, but there is no subject-object homoousion, for ViṣnuNārāyaṇa is Kṛṣna ontologically both by way of personal identity as the essence of Brahman and the material of the divya rūpic manuși tanu.

By way of origination ex deo, Rāmānuja's theōsis is in the functional sense instantiated at the origination of embodiments; yet, since the prakrti (matter) of embodiments is contingent upon the Lord's actual being, we also have theōsis in the ontological sense. As for individual ātman$s$, they are everlasting modes of Viṣnu-Nārāyaṇa (Gìtā 15.7) and everlastingly contingent upon his actual being-thus the functional and ontological also apply here, in contrast to Torrance.

Though sharing with Rāmānuja the notion of personalism, Torrance does not advocate monopersonalism. ${ }^{26}$ Torrance's triune personalism and unqualified deity-creation dualism affected his notion of theōsis where the believer does not possess the ontological nature of God because God is wholly other. ${ }^{27}$ Thus, theōsis entails coming into a partaking of the living presence of God by the indwelling of the Spirit. Rāmānuja's theōsis views all humanity partaking ontologically and functionally of the divine essence by way of God as material cause and indwelling presence, the latter by way of antaryamin. Thus, if there is with Rāmānuja a coming into, it is by way of realization of something already in place.

Rāmānuja shares with Torrance the notion of all theological events taking place within the life of God. Predicates for "God" are important, and play into ontology that highlights differences. An example of this is incarnation and avatāra. With Torrance's orthodoxy we find God the Father sending God the Son (the logos) to incarnate in the womb of the Virgin Mary by the agency of God the Holy Spirit. Further, "fullness of time" is one cause for the incarnate Son's reconciling atoning work through the Holy Spirit (Galatians 4.4-6). With Rāmānuja, when licentiousness peaks ("fullness of time"), the Lord descends to human form with no other than himself as supreme agent: "I come into being in material forms by my own power ... I send forth myself" (Gìtā 4.6-7 ${ }^{28}$ ). Additionally, just as Torrance argues that the ontological Trinity "is essentially and intrinsically evangelical" ${ }^{29}$ and expresses itself in God's economy through the incarnation (though the ontological and the economic cannot be radically dualized due to 
"the Being of God in his acts and the acts of God in his Being"), Rāmānuja likewise could argue the same regarding his mono-personalisminherent in Viṣnu-Nārāyaṇa's being (ontological) is desire to send forth himself (economy). Economy, then, finds its ground in ontology.

As just mentioned, with Rāmānuja there is a "fullness of time" context for avatāra. Gìtā 4.7 points to the decline of righteousness (dharma) and the rise of unrighteousness (adharma). There is also a reconciling to and communion with the Lord, ${ }^{30}$ i.e., a theossis, though there is no substitutionary atonement as ground. Notionally similar to Christianity, reconciliation is personal, reciprocated devotional service to God, in this case bhakti (devotion) to NārāyaṇaKrșna. Adding the dynamic of the horizontal (devotees to devotees to all beings) to this theōsis, we have a fully orbed onto-relations whereby devotees become "truly human" in the here and now (see the three points at the end of this essay).

In Rāmānuja's Vedānta, theōria as contemplation of the divine is a way toward (and is) participation in the divine life (theōsis), both here and now and in the eschaton. As is the case with Torrance, important is the preposition: in the divine life. Torrance understands it as believers' contemplation "in union with" the Triune God and in union with one another by way of relationship, with no ontological sharing of the divine essence. Here, transformed and wholly-other humanity continues everlastingly in the eschatological age. With Rāmānuja the eschatological age (here defined as escape from samsāra [the cycle of death and rebirth]) involves everlasting, embodied ${ }^{31}$ relational unity with ViṣnuNārāyaṇa and relational unity with other released devotees as both deity and devotees share in the ontological divine essence.

Gìtā 11.54-55 provides a basis for Rāmānuja's theōsis (participation) and theōria (contemplation) and parallels Torrance's use of 2 Peter 1.4. Gìtā 11.54-55 reads, "By devotion not directed to another am I able truly to be known in such a manner, $O$ Arjuna, and to be beheld and truly be entered, O scorcher of foes. He who is performing action for my sake, has me as the highest object, is devoted to me, who has abandoned all other attachment and is free from animosity toward all beings, he goes to me, $\mathrm{O}$ son of Pāṇụ." This evidences participation and contemplation in and toward the divine. "By devotion" ${ }^{32}$ directed to no other is the Lord "known" ${ }^{33}$ and "beheld." ${ }^{34}$ The fruit of this theōria, which we may say is jñanna marga (the path of knowledge), is realized theossis, where the Lord is "entered," ${ }^{35}$ which is realization of an already-instantiated ontological oneness and coming into a reciprocated bhakti relationship with the Lord. With this ontological sharing of essence is the functional: devotees participate in the divine life by performing action "not directed to another"; "performing action for my sake" with "me as the highest object." Harmoniously, the fruit of the vertical is the horizontal: "free from animosity toward all beings." 36

Finally, to see in Rāmānuja the teaching of "truly human" takes some creative thinking. Below are three points. The first two are foundational to a comparison of Rāmānuja with Torrance, though they bring to light some differences between them amidst notional similarities. The third point argues for a "truly human" doctrine in Rāmānuja.

First, Rāmānuja's view of matter and its cause, function, and ultimate worth lends to radical 
differentiation between his eschatology and Torrance's eschatology. Though Rāmānuja's viśisțādvāita posits a real universe, a future reconciling reordering of a "once was" singular created universe and humanity is not the goal. As opposed to Christianity's linear view of a single-occurring history, samsāric yugic cycles ${ }^{37}$ occur eternally ${ }^{38}$ with Viṣnu-Nārāyaṇa both as material cause and dissolution (Gitā 7.6). In this sense there is no consummating event for material humanity in order to bring it fully to what it was intended to be.

Second, in light of materiality ultimately being a secondary concern, ${ }^{39}$ and matter coming into being and dissolution in eternal cycles, Rāmānuja's notion of the liberated àtman lends to the conclusion that there is no emphasis on preserving a material humanness and personality that "once was" in a singular

\section{Notes}

${ }^{1}$ See Myk Habets, Theosis in the Theology of Thomas Torrance (New York: Routledge, 2016). Habets notes that Torrance in his academic career rarely employed the word theossis and devoted little space to it (due to a general dislike of the notion in Western theology [though it is gradually becoming popular], including Torrance's Reformed tradition). "His theology is, however, profoundly compatible with, and shaped by, the central themes associated with doctrines of theosis" (2). As a result, one must glean from writings and lectures by Torrance and employ "creative imagination in a manner that is tested and controlled by Torrance's own concerns" (ibid.). In this essay I do the same with Rāmānuja.

2 "The closest English equivalent of theōsis is 'deification" (Stephen Finlan and Vladimir Kharlamov, "Introduction," in Stephen Finlan and Vladimir Kharlamov, Theōsis: Deification in Christian Theology. Two vols. [Eugene, OR: Pickwick Publications, 2006], 1:1). Finlan and Kharlamov note creation event. ${ }^{40}$ This differs radically with Torrance.

Yet, third, one could still conclude that in a profoundly Hindu sense, Rāmānuja captures the thought that to be truly human in the here and now is to recognize that "human" is prakrtic and "not-ätman" while the âtman is eternal and not subject to change. ${ }^{41}$ On the heels of this are theōria and theossis. To be truly human is to contemplate the true nature of the eternal individual àtman (Gìtā 2.20), "which is of the nature of meditation" and is "the supreme consummation." ${ }^{42}$ That is theōria. To be truly human is to fulfill one's dharma (duty [according to caste]) in both the vertical and the horizontal in the real, prakrtic world and in participation with the divine. ${ }^{43}$ That is theōsis.

that though Gregory of Nazianzus (AD 329-390) coined the term, Christian theologians have understood the term differently (1:1). Further, despite the early Church theologians' fascination with theōsis, "the fathers do not develop a 'doctrine' of theōsis. Nor do the doctrinal controversies of the Church Councils deal with the subject" (1:4).

${ }^{3}$ Torrance did not accept all the theology of the East. He rejected some points (Habets, Theosis in the Theology of Thomas Torrance, 8). Yet, theōsis was not entirely shunned by the Western tradition. Habets mentions Augustine and Aquinas being aware of theōsis as "partakers of the divine nature by grace" (Theosis in the Theology of Thomas Torrance, 9). Also, some have detected theosis in the theology of John Wesley, particularly Wesley's doctrine of entire sanctification (or Christian perfection). See Albert C. Outler, John Wesley (New York: Oxford University Press, 1964), 9-10; and Edmund J. Rybarczyk, Beyond Salvation: Eastern Orthodoxy and Classical Pentecostalism 
on Becoming Like Christ (Waynesboro, GA: Paternoster, 2004), 9-15.

${ }^{4}$ See Athanasius' De Incarnatione and Apologia Contra Arianos. See also Basil Studer, "Divinization," in Angelo Di Beradino, Encyclopedia of the Early Church. Two vols. (New York: Oxford University Press, 1992), 1:242. The incarnation is at the heart of the theology of theōsis (cf. Finlan and Kharlamov, "Introduction," in Theōsis: Deification in Christian Theology, 1:4).

${ }^{5}$ As did John Calvin. See Myk Habets, "Reforming Theōsis," in Finlan and Kharlamov, Theōsis: Deification in Christian Theology, 1:152.

${ }^{6}$ Thomas F. Torrance, The Christian Doctrine of God: One Being, Three Persons (Edinburgh: T\&T Clark, 1996), 32-34.

${ }^{7}$ Thomas. F. Torrance, The Mediation of Christ (Colorado Springs: Helmers and Howard Publishers, 1992), 99-100; Habets, Theosis in the Theology of Thomas Torrance, 3-4.

${ }^{8}$ Further, due in part to Einsteinian relativity theory and quantum mechanics, Torrance argued for a unitary model of science as it relates contingently to the Triune God. See Man Kei Ho, A Critical Study on T. F. Torrance's Theology of Incarnation (Bern, Switzerland: Peter Lang, 2008), 54-57.

${ }^{9}$ Habets, Theosis in the Theology of Thomas Torrance, 1-2, quoting Torrance's Theology in Reconstruction (Grand Rapids: Eerdmans, 1965), 243.

${ }^{10}$ Among others, John 10.34-35 and 17.20-23; Acts 17.28; Genesis 1.26-27; "sonship" in Galatians 4.5-7 and Romans 8.15; and Matthew 5.48. Finlan and Kharlamov ("Introduction," in Theōsis: Deification in Christian Theology, 1:2) note Christian theological themes to which the term may apply: imitation of God (Ephesians 5.1); taking on God's nature (John 10.34); indwelt by God (John 14.7); being reformed by God (Ephesians 4.24); and being con-formed to Christ (2 Corinthians 3.18).

${ }^{11}$ Torrance, The Christian Doctrine of God, 95. He calls "deification" as a translation of theōsis "misleading," "Platonising," and agrees with Florovsky's "embarrassing" when it comes to the word theōsis itself (Georges Florovsky, "St Gregory Palamas and the Tradition of the Fathers," in Georges
Florovsky, Bible, Church, Tradition: An Eastern Orthodox View [Belmont, 1972]. Two vols. Collected works, 2:115). Finlan and Kharlamov mention other translations of the term: union; participation; partaking; communion/partnership; divine filiation; adoption; recreation; intertwined with the divine; similitude with God; transformation; elevation; transmutation; commingling; assimilation; intermingling; rebirth; regeneration; and transfiguration ("Introduction," in Theōsis: Deification in Christian Theology, 1:6). Theopoiēsis, "making divine," is a related term.

12 Koinōsis-"sharing," "fellowship," "participation"-rather than theōsis, might be a better theological term around which to build the doctrine.

${ }^{13}$ From theōreō, "I contemplate."

${ }^{14}$ I will not here delve into Torrance's distinction between "being" and "person." Readers may consult Myk Habets, "Reforming Theōsis," 153-58.

${ }^{15}$ Torrance, The Mediation of Christ, 110.

${ }^{16}$ See Habets, Theosis in the Theology of Thomas Torrance, 8. The influence of Athanasius upon Torrance is evident. Habets recalls Athanasius' theology: "it is clear that ... theosis is the means of salvation whereby the human person is incorporated, not into the divine essence, but into the person of Christ who, by virtue of the hypostatic union, is the mediator of divinity" (7).

${ }^{17}$ Torrance, The Christian Doctrine of God, 151.

${ }^{18}$ Following Sheridan I employ "originates." Daniel P. Sheridan, "The Asymmetry of 'Origination' and 'Creation': Contrasts within Comparative Theology." Journal of Hindu-Christian Studies, 2015 (no. 28): 76-87. See Gìtā 7.6.

${ }^{19}$ See also Gitā 7.13 and Bṛhadāranyaka Upanișad 3.6; 3.7.1; 3.8.6-8. All translations of the Gità are from Steven Tsoukalas, Bhagavad Gitā: Exegetical and Comparative Commentary with Sanskrit Text, Translation, Interlinear Transliteration with Parsing, Mini Lexicon, and Text-Critical Notes. Six vols. (Lewiston, NY: The Edwin Mellen Press, 2007, 2008, 2008, 2010, 2012, 2015).

${ }^{20}$ For more on Rāmānuja's epistemology and ontology see my Krșna and Christ: Body-Divine Relation 
in the Thought of Sanikara, Rāmānuja, and Classical Christian Orthodoxy (Carlisle: Paternoster, 2006), 56-70, 91-116. For extended treatments of Rāmānuja's theology see John B. Carman, The Theology of Rāmānuja: An Essay in Interreligious Understanding. Reprint 1974 (Bombay: Ananthacharya Indological Research Institute, 1981); and Julius J. Lipner, The Face of Truth: A Study of Meaning and Metaphysics in the Vedāntic Theology of Rāmānuja (Albany: State University of New York Press, 1986).

${ }^{21}$ See J. A. B. van Buitenen, trans., Rāmānuja's Vedärthasamgraha (Poona: Deccan College Postgraduate and Research Institute, 1956), 282-83. RVed from here on.

${ }^{22}$ Which some have seen as similar to the indwelling of the Holy Spirit. Ninian Smart, "The Inner Controller: Learning from Ramanuja," in David C. Scott and Israel Selvanayagam, eds., Re-Visioning India's Religious Traditions: Essays in Honour of Eric Lott (Delhi: ISPCK, 1996), 145; Carman The Theology of Rāmānuja, 256.

${ }^{23}$ Due to karma, ignorance includes not seeing Viṣnu-Nārāyaṇa as the Self of individual selves.

${ }^{24}$ Carman states, "the Supreme Person ... who is completely self-sufficient and independent ... takes our mortal form upon Himself in order to benefit the world" (The Theology of Rāmānuja, 258).

${ }^{25}$ Tsoukalas, Krșna and Christ, 244.

${ }^{26}$ I proceed with the notion of a supremely ultimate mono-personalism where Viṣnu-Nārāyaṇa alone possesses eternal supreme existence and attributes and alone is the Highest. Carman advances that Rāmānuja saw Viṣnu-Nārāyaṇa's eternal consort Śrī (Lakșmī) sharing "a close likeness in nature," yet "a clear subordination to Him" (The Theology of Rāmānuja, 239; see Carman's brief remarks on two later divisions of Viśiștādvāita: Vaḍagalais and Tengalais [238]). For extended treatment see 238-48. Lipner, however, in the context of his discussion on means of salvation, states, "we have said little or nothing about the role of Śrī, the divine consort, in Rāmānuja's theology. This is because there is little or nothing to say" (The Face of Truth, 115). Yet, Lipner notes that Śrī played more than a small part in
Rāmānuja's theological outlook and in Śrī-Vāișnavite devotion (116). Carman admits to the brief nature of Rāmānuja's comments in RVed regarding Śrī (238). For example, Rāmānuja in paragraph 127 briefly mentions (through quoting scriptures) Śrī in the context of describing the divya rūpa. Readers should note, though, that Rāmānuja in RVed paragraph 133 quotes Viṣnu Purāṇa: “Śrī, Viṣnu’s faithful consort ... is eternal herself, and she is omnipresent even as Vișnu Himself is. When He is god, she assumes a divine body, when He is man she assumes a human body" (Van Buitenen's translation). Carman calls this Śrì's "inseparability from Vișnu" (The Theology of Rāmānuja, 240). Yet, he also notes that in Rāmānuja's theology Śrī is given no distinct function; she merely accompanies the Lord $(243,247)$. See also Śrīnivāsadāsa $\left(17^{\text {th }}\right.$ century), Yatīndramatadīikika (Svāmī Ādidevānanda, trans., Mylapore: Sri Ramakrishna Math, n.d.). At the end of a section on Íśvara and his attributes (9.29)-which evidences my view that Śrī is a personified eternal attribute of the Lord-Śrīnivāsadāsa briefly mentions Śrī’s everpresence with the Lord. Further, Śrīnivāsadāsa confesses the Lord as "the sole Reality, one without a second" (1.1). Where one lands on this discussion affects the comparative venture. For example, who is present when Viṣnu-Nārāyaṇa descends to take human form? Agreeing with Carman could lead to seeing similarity with the Christian doctrine of the Father sending the Son.

${ }^{27}$ By virtue of the divya rupa there is with Rāmānuja a qualified sense of the originated universe as other (see Carman, The Theology of Rāmānuja, 256).

${ }^{28}$ samibhavāmyātmamāyayā $\quad$... ātmānam sțjāmyaham.

${ }^{29}$ The Christian Doctrine of God, 109.

${ }^{30}$ See also Carman, The Theology of Rāmānuja, 61. This is through what Carman calls supremacy and accessibility. See 190-98 for Carman's extensive treatment of God's "special relationship" with devotees. This special relationship is in part "attaining Brahman" (221). Also, see "he goes to me" (Gìtā 11.55). 
${ }^{31}$ In Rāmānuja's eschatology the liberated ātman can acquire bodies (not affected by prakrti or karma) at will. Lipner states, "Rāmānuja allows for the liberated attman to assume at will, in furtherance of its power and enjoyment, non-prakrtic, apparently anthropomorphic, bodies" (The Face of Truth, 119).

${ }^{32}$ bhaktyā.

${ }^{33} \vee j n \tilde{a} \bar{a}$, from which comes jñāna (knowledge), vital as a means of liberation.

${ }^{34} \sqrt{ } d r s^{\prime}$.

${ }^{35}$ pravviś.

${ }^{36}$ See Rāmānuja's commentary on 11.55 in Svāmī Ādidevānanda, trans., Śrī Rāmānuja Gìtā Bhāṣya (Mylapore: Sri Ramakrishna Math, n.d.), 394. P. N. Srinivasachari states that bhakti and prapatti (surrender and spirituality) "go together as the vertical and horizontal ways of expressing love" (Preface to Śrīnivāsadāsa's Yatīndramatadīikikā).
${ }^{37}$ The cycles of time, from purest to most impure: Satya or Kṛta, Treta, Dvāpara and Kali.

${ }^{38}$ However, since yugic cycles occur eternally, the cycles themselves can be seen as occurring in eternal, linear fashion.

${ }^{39}$ See Gìtā 2.18 in the context of Gìtā 2.12-25.

40 "Not all religions take it so far as to develop a concept of theōsis while still preserving human personal identity, as Christianity does" (Finlan and Kharlamov, "Introduction," in Theōsis: Deification in Christian Theology, 1:4).

${ }^{41}$ Ādidevānanda, Śrī Rāmānuja Gìtā Bhāṣya, 604.

${ }^{42}$ Ādidevānanda, Śrī Rāmānuja Gìtā Bhāṣya, 585.

${ }^{43}$ For example, Gìtā 18.46 speaks of performing one's dharma in worship of the Lord. With this, "man attains perfection" (Ādidevānanda, Śrī Rāmānuja Gìtā Bhāṣya, 582). 